\title{
Sociodemographic Disparities and Self-reported Oral Health Problems Associated with Pregnancy: A Case-control Study in Morocco
}

\author{
Rachid Ait Addi ${ }^{1 \star}$, Abdelhafid Benksim ${ }^{1,2}$, Loubna Bahije ${ }^{3}$, Mohamed Cherkaoui ${ }^{2}$
}

\author{
${ }^{1}$ Laboratory of Human Ecology, Department of Biology, School of Sciences Semlalia, Cadi Ayyad University, Marrakesh. MOROCCO \\ ${ }^{2}$ High Institute of Nursing and Technical Health, Marrakesh, MOROCCO \\ ${ }^{3}$ Department of orthodontics, School of dentistry of Rabat, Mohamed V university, Rabat, MOROCCO \\ *Corresponding Author: dr.rachid.aitaddi@gmail.com
}

Citation: Ait Addi R, Benksim A, Amine M, Cherkaoui M. Sociodemographic Disparities and Self-reported Oral Health Problems Associated with Pregnancy: A Case-control Study in Morocco. Electron J Gen Med. 2020;17(5):em249. https://doi.org/10.29333/ejgm/8238

\section{ARTICLE INFO}

Received: 30 Nov. 2019

Accepted: 17 Apr. 2020

\begin{abstract}
Background: Dental and periodontal diseases are a public health problem over the world, however little is known about individual characteristics or behaviors associated with self-reported oral status during pregnancy. This cross-sectional study examines the relationships between pregnancy and Dental and Periodontal Health (DPH), socio-demographic factors and DPH, and health behavioral factors and DPH.
\end{abstract}

Study design: This study adopted a cross-sectional, descriptive and correlational research design to investigate the current oral health related health behavior, and socio-demographic disparities in pregnant and non-pregnant women in the MARRAKESH region in Morocco.

Methods: Participants ( $n=539,251$ pregnant, and 288 non-pregnant women), recruited from two health centers in the Marrakesh region (urban and rural), completed questionnaires addressing: Education, economic status, dental insurance, self-reported DPH, oral hygiene practices, and dental care utilization.

Results: 162 women were urban and 87 were rural in the pregnant group, while 226 women were urban vs 62 in the non-pregnant group. Also, 181 women were educated and 68 were illiterate in the pregnant group while 238 women were educated and 50 were illiterate in the non-pregnant women group. Moreover, pregnant women brush less frequently than non-pregnant women, dental visits were more important amongst non-pregnant women than pregnant women, and only 37 pregnant women visited a dentist while 82 pregnant women visited a dental quack. Conclusion: This study highlights the effect of pregnancy and sociodemographic disparities on self-reported DPH, and provides useful findings for preventive and therapeutic interventions.

Keywords: pregnancy, dental health, periodontal health, sociodemographic, dental quack

\section{INTRODUCTION}

Fairly four billion people over the world are affected by oral diseases $(1,2)$. Tooth decay is one of the most frequent oral diseases which is an infectious disease due to biological, behavioral and socioeconomic factors and causing pain and stress with negative effects on the quality of life of pregnant women (3-5). Pregnancy is a state of progressive physical, psychological, and hormonal changes $(6,7)$. Poor oral health during pregnancy may due to a limited attention to oral hygiene, leading to an increasing physical and emotional demands (8). Poor oral hygiene, increased acidity in the oral cavity, sugary dietary and hormonal changes increase the risk of developing oral health problems such as dental decay, gingivitis or gingival inflammation and periodontitis (8-10). Increased levels of Streptococcus mutans and Lactobacillus may increase the risk of tooth decay amongst Pregnant women (11). Gingivitis is an inflammatory disease affecting the supporting tissues of the tooth (9). As well as associated with pregnancy, gingivitis is initially occurred by dental plaque and after aggravated by steroid hormones essentially progesterone and a decreased immune response (8). Around $60 \%$ to $75 \%$ of pregnant women have gingivitis, and near half of pregnant women in the United States have periodontitis which correspond to gingivitis with gingival recession accompanied by loss of connective tissue and alveolar bone $(8,12)$.

Many factors independent of pregnancy could also play an important role such as demographic and socioeconomic status, health practices and health care utilization, and finally the broader social context and environment (5,13-18).

In addition, many studies proved that Maternal periodontal disease has been associated with preterm birth, development of preeclampsia, and delivery of a small-for-gestational age infant. Also, maternal oral flora is transmitted to the newborn infant, and increased cariogenic flora in the mother predisposes the infant to the development of caries (19).

Several studies were conducted over the world to assess the oral health status of pregnant women. The studies of Ait 
addi et al, and Sidqui et al were the only ones conducted in Morocco, which compared the dental and periodontal status of pregnant women and non-pregnant women. Both of the studies found a high degree of tooth mobility in the pregnant women and a poor dental and periodontal health status amongst pregnant and non-pregnant women. However, the samples of the two studies were small (respectively 105 and $100)$ and the socio-economic and behavioral factors were not assessed. Also, no study in Morocco has been performed on oral health behaviors nor to assess dental quackery.

The objectives of this study were to assess the dental and periodontal health in a sample of pregnant women compared to non-pregnant women in the Marrakesh region in Morocco, and to study the associated risk indicators such as sociodemographic and behavioral factors.

\section{MATERIALS AND METHODS}

\section{Study Design, Setting and Participants}

This study adopted a cross-sectional, descriptive and correlational research design to investigate the current oral health related health behavior, and socio-demographic disparities in pregnant and non-pregnant women in the Marrakesh region in Morocco.

Actually, the Marrakesh region ( $31^{\circ} 37^{\prime} 48^{\prime \prime} \mathrm{N} 8^{\circ} 00^{\prime} 00^{\prime \prime} \mathrm{W}$ ) is located in the center of the country, includes a part of the High Atlas Mountains, and populated by 4520569 habitants with 1 938016 living in the urban area and 2582553 living in rural area (20).

Participants were recruited from two health centers urban and rural by simple random sampling method from August 2015 to July 2017 without previous appointment. In fact, the study recruited 539 women, with 251 pregnant, and 288 nonpregnant women whom consulted for Checkups of pregnancy, or for contraception and met the following selection criteria:

Inclusion criteria: Aged 18-40 years.

Exclusion criteria:

a) Women with more than 10 missing teeth.

b) Women with any systemic health conditions such as diabetes, cardiovascular diseases or blood dyscrasias.

\section{Outcomes and Measurements}

A structured self-administered questionnaire was used to explore the socio-demographic background, oral health status, attitude and practices of the participants.

The questionnaire was evaluated by a local committee as valid and reliable, and consisted of three parts:

Part one included socio-demographic characteristics including age, living environment (we classified our subjects as either from rural or urban area), number of pregnancies, occupation, dental insurance, educational level attained.

In Part two, oral health behavior was assessed with questions on tooth brushing frequency and method, dental visits, and where they did dental visits: if the visit was done with a qualified dentist or with a person who is not qualified but do visits illegally "dental quack" (we distinguish between a qualified dentist and a quack dentist by the presence or not of the government registration number).
Finally, in the part three Self-reported oral health status was assessed by questions on dental and periodontal status. They respond by yes or no if they have: Dental abscess, dental mobility, dental decay, gingival recession, dental loss, periodontitis, and calculus.

All data were collected by qualified nursing students for a better comprehension.

\section{Data Collection Procedure}

The researchers recruited women who were currently undergoing the health centers in the study. Potential participants were given an information sheet explaining the study's aims, procedures, their responsibility, possible benefits, alternatives to participation, confidentiality of data and voluntary participation. Those who were willing to participate, provided verbal consent to take part in the study. Following this, they were given a self-administered questionnaire, which took about $15 \mathrm{~min}$ to complete. This was conducted in a private room to ensure privacy.

A token of appreciation was given to each participant after they had completed the questionnaire.

\section{Ethical Considerations}

The participants were questioned after having the full explanation of the purpose of our study and receiving their consent. The consent procedure was approved by the health ministry delegation. Also, our study has been independently reviewed and approved by the health ministry delegation. We note that we have not yet a local ethics committee because of that the health ministry delegation ensures that function. Finally our research has been conducted in full accordance with the World Medical Association Declaration of Helsinki http://www.wma.net/en/30publications/10policies/b3/index. html

\section{Statistical Analysis}

Data was entered and analyzed by SPSS ver. 13.0 (Chicago, IL, USA). The number of women is calculated in each question which they have responded.

Descriptive statistics were computed to compile data for the demographics and other key variables of interest.

The economic status was based on the type of profession and the presence or not of dental insurance.

In addition, response for self-perception of oral health status was also categorized for data analysis. The correlation between oral health determinants, sociodemographic factors and the oral health status was analyzed using chi-square. The level of statistical significance was set at $p_{-} 0.05$.

\section{RESULTS}

Overall, 539 women were included in this study whose 251 (46.56\%) pregnant and 288 (53.44\%) non pregnant women.

The living environment showed a high significant difference between pregnant and non-pregnant women $(P=0.001)$, in fact there were less pregnant women living in the urban area than non-pregnant women (Figure 1, B). According to educational level, a high significant difference was noted between pregnant and non-pregnant group with more illiteracy amongst pregnant women that non-pregnant women (Figure 1, C). It was also shown that there was a high significant 
Age classes of pregnant and non-pregnant women

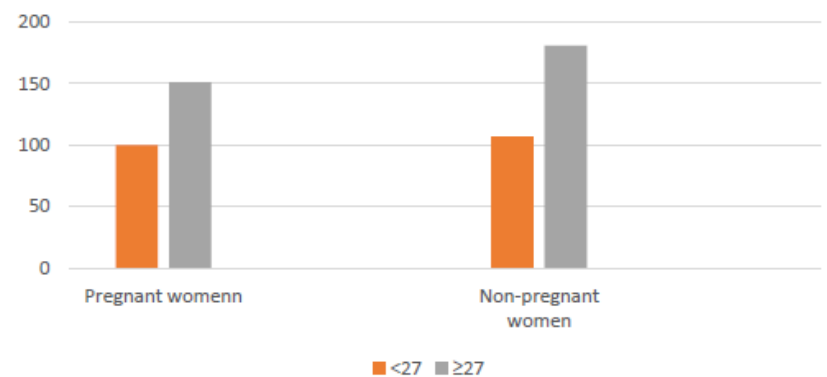

A: Age classes of pregnant and non-pregnant women Environment living

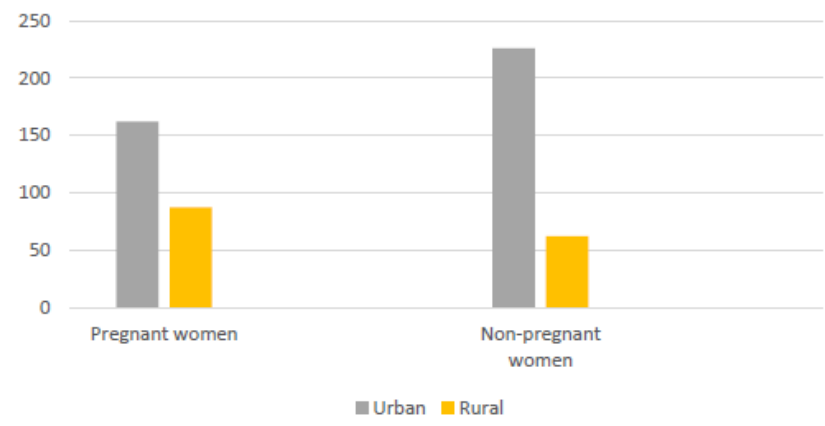

B: Environment living of pregnant and non-pregnant women Education of pregnant and non-pregnant women

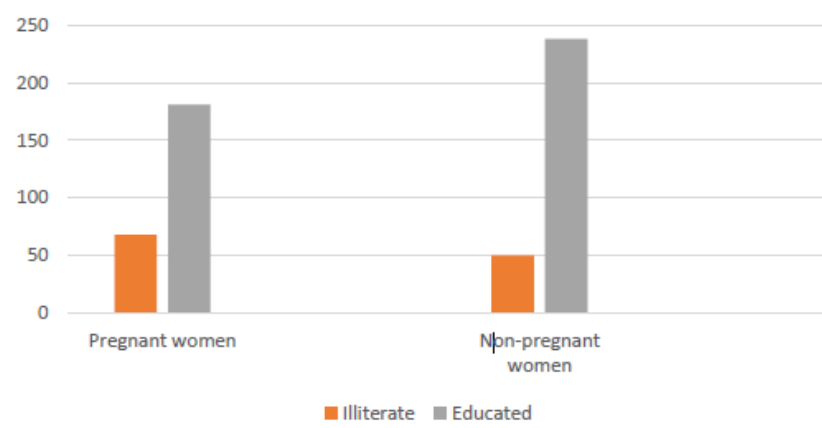

C: Education of pregnant and non-pregnant women Economic status of pregnant and non-pregnant women

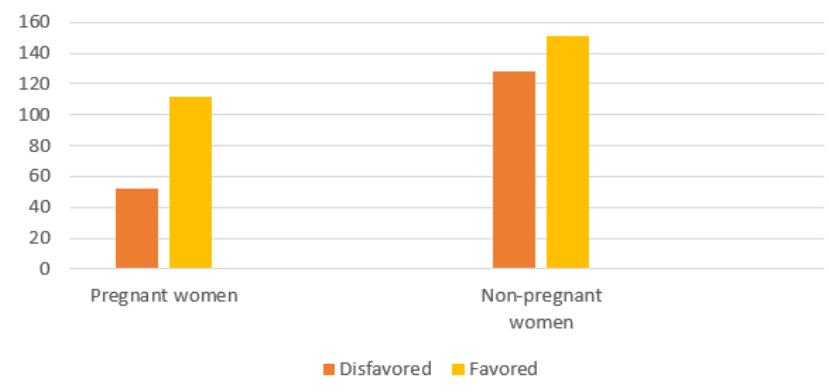

D: Economic status of pregnant and non-pregnant women

Figure 1. Socio-demographic characteristics of pregnant and non-pregnant women (A, B, C, D, E, F)

difference in the economic status between the two groups. Indeed, pregnant women were more favored than nonpregnant women (Figure 1, D).

In comparison to pregnant women pregnant women brushed their teeth less frequently than non-pregnant women (Figure 2, A).
Dental insurance of pregnant and non-pregnant women

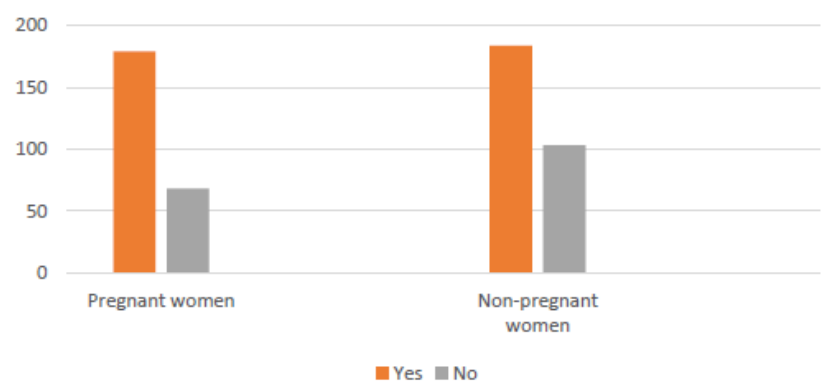

E: Dental insurance of pregnant and non-pregnant women Parity of pregnant and non-pregnant women

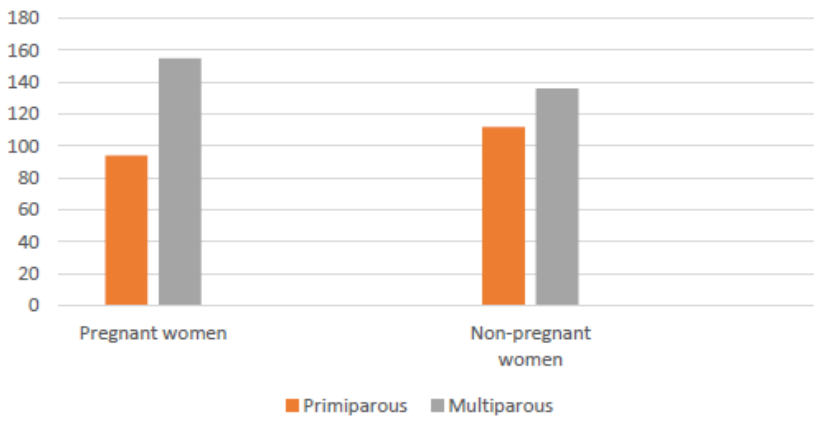

F: Parity of pregnant and non-pregnant women

Figure 1 (continued). Socio-demographic characteristics of pregnant and non-pregnant women (A, B, C, D, E, F)

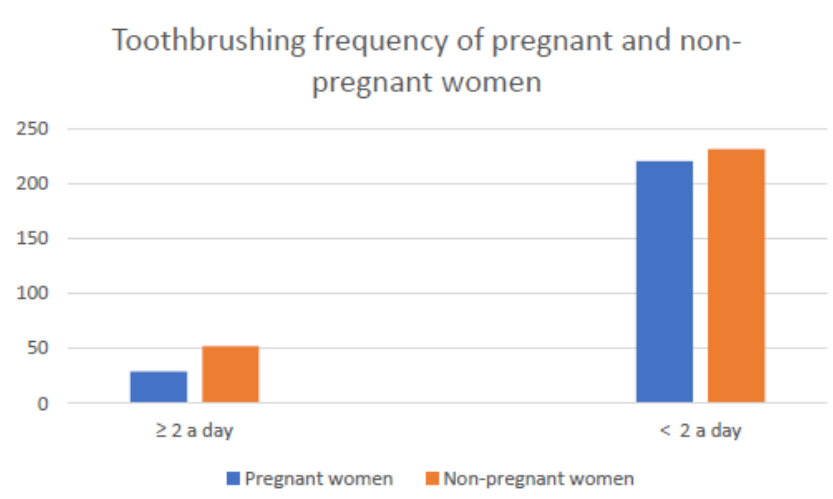

A: Toothbrushing frequency of pregnant and non-pregnant women

Figure 2. Oral health characteristics between pregnant and non-pregnant women (A, B, C, D, E)

Also, pregnant women used the right tooth brushing method more that non-pregnant women, however pregnant women were using less other method than non-pregnant women (Figure 2, B). Furthermore, dental visits were noted more in the non-pregnant group than the pregnant women group, and only 37 pregnant women visited a dentist while 82 pregnant women visited a dental quack (Figure 2, D, E).

In self-reported oral health, pregnant woman had significantly more dental decay, dental abscess, dental mobility, dental loss, gingival recession, periodontitis and calculus than non-pregnant women (Figure 3). Living environment showed a significant difference in periodontitis, gingival recession, dental loss, dental decay, and dental mobility which were more important amongst rural women that urban women (Figure 4). Significant differences were 
Toothbrushing method

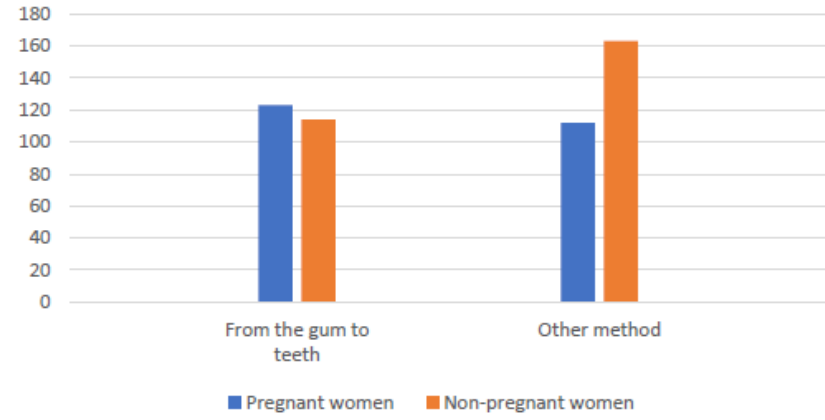

B: Toothbrushing method of pregnant and non-pregnant women

Frequency of Flossing

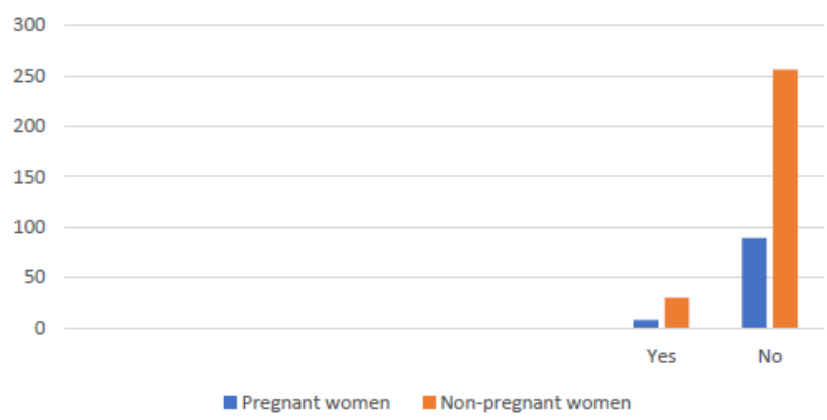

C: Frequency of flossing of pregnant and non-pregnant women

Dental visits

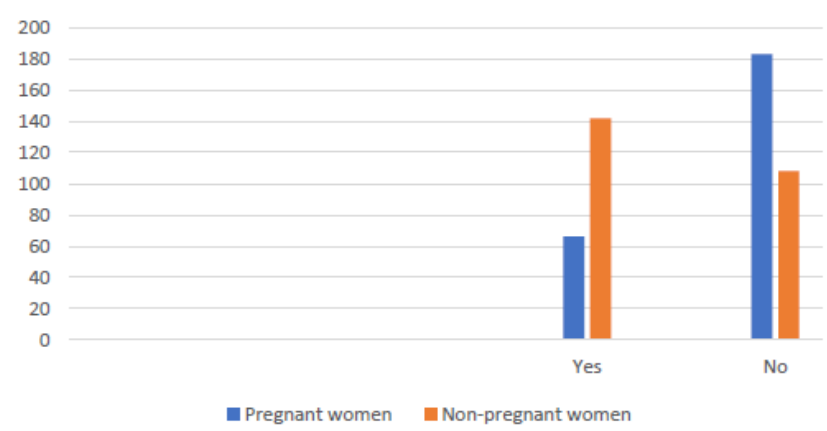

D: Dental visits of pregnant and non-pregnant women

Dental visits

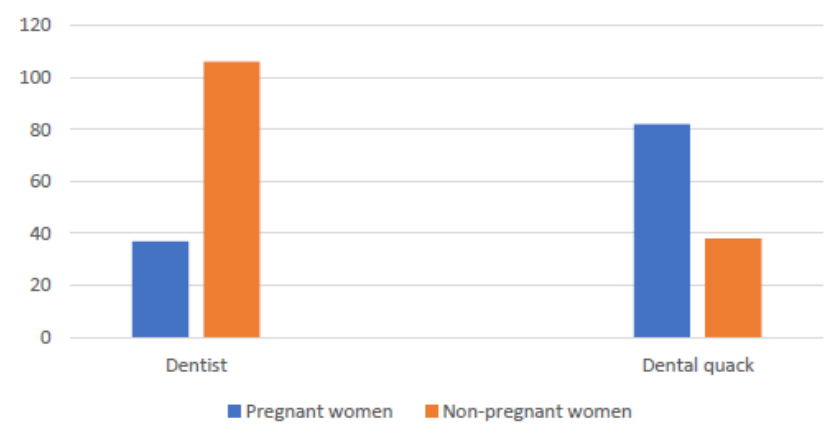

E: Dental visits location of pregnant and non-pregnant women

Figure 2 (continued). Oral health characteristics between pregnant and non-pregnant women (A, B, C, D, E)

recorded in dental abscess, gingival recession, dental loss, and periodontitis which were more important in illiterate women that educated women (Figure 5).
Dental and periodontal diseases

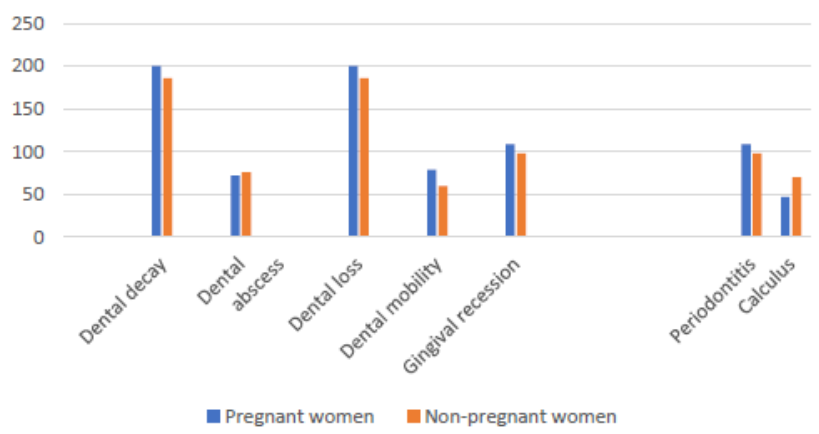

Figure 3. Dental and periodontal diseases of pregnant and non-pregnant women

Dental and periodontal diseases of urban and rural women

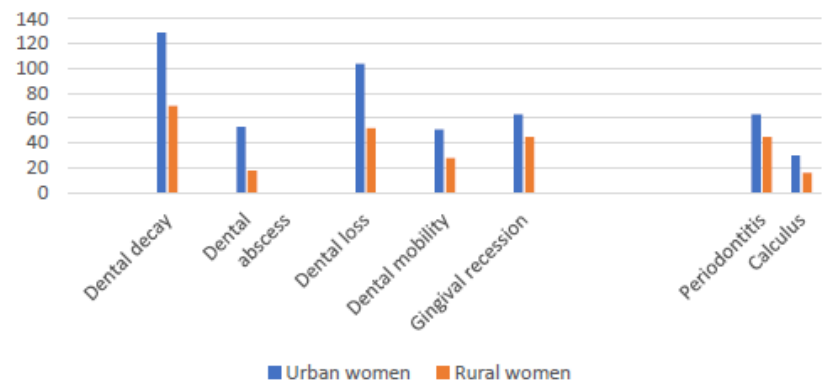

Figure 4. Dental and periodontal diseases and environment living

Dental and periodontal diseases and education

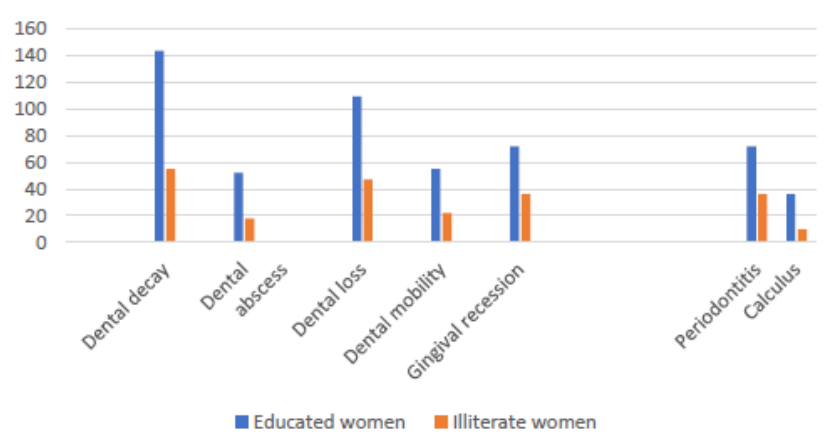

Figure 5. Dental and periodontal diseases of pregnant and non-pregnant women

\section{DISCUSSION}

To our knowledge this is the first study which has explored dental quackery and socio-demographic disparities related to oral health behavior among women in Morocco.

The study reported that $87.72 \%$ of pregnant women had dental decay vs $74,7 \%$ of non-pregnant women which is highly significant and may be explained by the increased acidity in the oral cavity, sugary dietary cravings, and limited attention to oral health (21). In contrary, the study of Ait addi et al (2018), reported no significant difference in DMFT index (Decaymissing-filled index) between pregnant women and nonpregnant women. Also, Chung and al reported in a survey of 99 pregnant women that $45 \%$ had untreated dental decay $(22,23)$.

Pregnant women had significantly more dental abscess, dental loss than non-pregnant women which may be explained by the fact that dental abscess and dental loss are dental 
Table 1. Socio-demographic and self-reported oral health behavior characteristics between pregnant and non-pregnant women

\begin{tabular}{|c|c|c|c|c|}
\hline \multicolumn{2}{|c|}{ Variables and modalities } & \multirow{3}{*}{$\begin{array}{c}\text { Pregnant women } \\
100(39.84 \%) \\
151(60.16 \%) \\
\end{array}$} & \multirow{3}{*}{$\begin{array}{c}\text { Non-pregnant women } \\
107(37.15 \%) \\
181(62.85 \%) \\
\end{array}$} & \multirow{3}{*}{$\begin{array}{c}\text { p value } \\
0.535\end{array}$} \\
\hline \multirow{2}{*}{ Age classes $(n=539)$ a } & $<27$ Years & & & \\
\hline & $\geq 27$ Years & & & \\
\hline \multirow{2}{*}{ Environment living $(n=537)$ a } & Urban & $162(65.06 \%)$ & $226(78.47 \%)$ & \multirow{2}{*}{$0.001^{\star \star}$} \\
\hline & Rural & $87(34.94 \%)$ & $62(21.53 \%)$ & \\
\hline \multirow{2}{*}{ Education $(n=537) \mathbf{a}$} & Educated & $181(72.69 \%)$ & $238(82.64 \%)$ & \multirow{2}{*}{$0.007^{\star \star}$} \\
\hline & Illiterate & $68(27.31 \%)$ & $50(17.36 \%)$ & \\
\hline \multirow{2}{*}{ Economic status $(n=443)$ a } & Disfavored & $52(31.71 \%)$ & $128(31.71 \%)$ & \multirow{2}{*}{$0.004^{\star \star}$} \\
\hline & Favored & $112(68.29 \%)$ & $151(54.12 \%)$ & \\
\hline \multirow{2}{*}{ Dental Insurance $(n=534)$ a } & No & $179(72.47 \%)$ & $184(64.11 \%)$ & \multirow{2}{*}{$0.041^{\star}$} \\
\hline & Yes & $68(27.53 \%)$ & $103(35.89 \%)$ & \\
\hline \multirow{2}{*}{ Parity $(n=497)$ a } & Primiparous & $94(37.75 \%)$ & $112(45.16 \%)$ & \multirow{2}{*}{0.102} \\
\hline & Multiparous & $155(62.25 \%)$ & $136(54.84 \%)$ & \\
\hline \multirow{2}{*}{ BMI classes $(n=379) \mathbf{a}$} & Subweight and normal weight & $69(53.9 \%)$ & $129(51.39 \%)$ & \multirow{2}{*}{0.665} \\
\hline & Overweight and obesity & $59(46.1 \%)$ & $122(48.61 \%)$ & \\
\hline \multirow{2}{*}{ Frequency of Tooth brushing $(n=534)$ a } & $\geq 2$ a day & $29(11.6 \%)$ & $52(18.31 \%)$ & \multirow{2}{*}{$0.039^{\star}$} \\
\hline & $<2$ a day & $221(88.4 \%)$ & $232(81.69 \%)$ & \\
\hline \multirow{2}{*}{ Tooth brushing method $(n=512)$ a } & From the gum to teeth & $123(52.34 \%)$ & $114(41.15 \%)$ & \multirow{2}{*}{$0.013^{\star}$} \\
\hline & Other method & $112(47.66 \%)$ & $163(58.85 \%)$ & \\
\hline \multirow{2}{*}{ Frequency of Flossing $(n=383)$ a } & Yes & $8(8.25 \%)$ & $30(10.50 \%)$ & \multirow{2}{*}{0.694} \\
\hline & No & $89(91.75 \%)$ & $256(89.50 \%)$ & \\
\hline \multirow{2}{*}{ Dental visit $(n=499)$ a } & Yes & $66(26.50 \%)$ & $142(56.8 \%)$ & \multirow{2}{*}{$0.000 \star \star$} \\
\hline & No & $183(73.5 \%)$ & $108(43.2 \%)$ & \\
\hline \multirow{2}{*}{ Dental visit with $(n=263)$ a } & Dentist & $37(31.09 \%)$ & $106(73.61 \%)$ & \multirow{2}{*}{$0.000 * \star$} \\
\hline & Dental quack & $82(68.91 \%)$ & $38(26.39 \%)$ & \\
\hline
\end{tabular}

a Chi-squared test

${ }^{*} P<0,05$ : statistically significant.

${ }^{\star \star} P<0,001$ : Highly significant.

Table 2. Clinical self-reported oral health characteristics and pregnancy, environment living, and educational level

\begin{tabular}{|c|c|c|c|c|c|c|c|c|c|}
\hline $\begin{array}{c}\text { Variables and } \\
\text { modalities }\end{array}$ & $\begin{array}{c}\text { Pregnant } \\
\text { women }\end{array}$ & $\begin{array}{c}\text { Non-pregnant } \\
\text { women }\end{array}$ & $\begin{array}{c}p \\
\text { value }\end{array}$ & $\begin{array}{c}\text { Urban } \\
\text { women }\end{array}$ & $\begin{array}{c}\text { Rural } \\
\text { women }\end{array}$ & $p$ value & $\begin{array}{c}\text { Educated } \\
\text { women }\end{array}$ & $\begin{array}{c}\text { Illiterate } \\
\text { women }\end{array}$ & $\begin{array}{c}P \\
\text { value }\end{array}$ \\
\hline Dental abscess & \multicolumn{2}{|c|}{$n=413 a$} & & \multicolumn{2}{|c|}{$\mathrm{n}=163 \mathbf{a}$} & & \multicolumn{2}{|c|}{$\mathrm{n}=162 \mathbf{a}$} & \multirow{3}{*}{$\begin{array}{c}0.04 \\
*\end{array}$} \\
\hline Yes & $72(43.9 \%)$ & $76(30.52 \%)$ & .006 & $53(40.77 \%)$ & $18(54.54 \%)$ & & $52(39.39 \%)$ & $18(60 \%)$ & \\
\hline No & $92(56.1 \%)$ & $173(69.48 \%)$ & & $77(59.23 \%)$ & $15(45.46 \%)$ & & $80(60.61 \%)$ & $12(40 \%)$ & \\
\hline Dental mobility & \multicolumn{2}{|c|}{$n=433 a$} & & \multicolumn{2}{|c|}{$\mathrm{n}=184 \mathbf{a}$} & & \multicolumn{2}{|c|}{$\mathrm{n}=183 \mathrm{a}$} & \multirow{3}{*}{$\begin{array}{l}0.1 \\
\mathrm{n} . \mathrm{s}\end{array}$} \\
\hline Yes & $79(42.70 \%)$ & $60(24.19 \%)$ & 00 & $51(37.5 \%)$ & $28(58.33 \%)$ & D & $55(38.73 \%)$ & $22(53.65 \%)$ & \\
\hline No & $106(57.3 \%)$ & $188(75.81 \%)$ & & $85(62.5 \%)$ & $20(41.67 \%)$ & & $87(61.27 \%)$ & $19(46.35 \%)$ & \\
\hline Dental decay & \multicolumn{2}{|c|}{$\mathrm{n}=477 \mathrm{a}$} & & \multicolumn{2}{|c|}{$n=227 a$} & & \multicolumn{2}{|c|}{$n=226 a$} & \multirow{3}{*}{$\begin{array}{c}0.65 \\
\text { n.s }\end{array}$} \\
\hline Yes & $200(87.72 \%)$ & $186(74,7 \%)$ & 0.000 & $129(84.32 \%)$ & $70(94.6 \%)$ & $\star$ & $143(86.66 \%)$ & $55(90.16 \%)$ & \\
\hline No & $28(12.28 \%)$ & $63(25.30 \%)$ & & $24(15.68 \%)$ & $4(5.40 \%)$ & & $22(13.34 \%)$ & $6(9.84 \%)$ & \\
\hline Gingival recession & \multicolumn{2}{|c|}{$n=476 a$} & & \multicolumn{2}{|c|}{$\mathrm{n}=189 \mathbf{a}$} & & \multicolumn{2}{|c|}{$\mathrm{n}=188 \mathrm{a}$} & \multirow{3}{*}{$\begin{array}{c}0.000 \\
\star \star\end{array}$} \\
\hline Yes & $109(57.36 \%)$ & $98(34.26 \%)$ & 0 & $63(45,98 \%)$ & $45(86.54 \%)$ & $0.000^{\star}$ & $72(49.65 \%)$ & $36(83.72 \%)$ & \\
\hline No & $81(42.64 \%)$ & $188(65.74 \%)$ & & $74(54.02 \%)$ & $7(13.46 \%)$ & & $73(50.35 \%)$ & $7(16.28 \%)$ & \\
\hline Dental loss & \multicolumn{2}{|c|}{$n=448 a$} & & \multicolumn{2}{|c|}{$n=196 a$} & & \multicolumn{2}{|c|}{$\mathrm{n}=195 \mathrm{a}$} & \multirow{3}{*}{$\begin{array}{c}0.014 \\
\star\end{array}$} \\
\hline Yes & $157(79.69 \%)$ & $145(57.76 \%)$ & $\begin{array}{c}0.000 \\
\star \star\end{array}$ & $104(75.92 \%)$ & $52(88.14 \%)$ & $\begin{array}{c}0.05 \\
\star\end{array}$ & $109(75.69 \%)$ & $47(92.15 \%)$ & \\
\hline No & $40(20.31 \%)$ & $106(42.24 \%)$ & & $33(24.08 \%)$ & $7(11.86 \%)$ & & $35(24.31 \%)$ & $4(7.85 \%)$ & \\
\hline Periodontitis & \multicolumn{2}{|c|}{$\mathrm{n}=481 \mathrm{a}$} & & \multicolumn{2}{|c|}{$\mathrm{n}=193 \mathbf{a}$} & & \multicolumn{2}{|c|}{$\mathrm{n}=192 \mathbf{a}$} & \multirow{3}{*}{$\begin{array}{c}0.000 \\
\star \star\end{array}$} \\
\hline Yes & $109(56.18 \%)$ & $98(34,14 \%)$ & $\underset{\star \star \star}{0.000}$ & $63(44.68 \%)$ & $45(86.53 \%)$ & $\underset{\star \star \star}{0.000}$ & $72(48.65 \%)$ & $36(81.81 \%)$ & \\
\hline No & $85(43.82 \%)$ & $189(65.86 \%)$ & & $78(55.32 \%)$ & $7(13.47 \%)$ & & $76(51.35 \%)$ & $8(18.19 \%)$ & \\
\hline Calculus & \multicolumn{2}{|c|}{$\mathrm{n}=186 \mathbf{a}$} & & \multicolumn{2}{|c|}{$n=55 a$} & & \multicolumn{2}{|c|}{$n=55 a$} & \\
\hline Yes & $47(83.92 \%)$ & $70(53.84 \%)$ & $\begin{array}{c}0.000 \\
\star \star\end{array}$ & $30(83.33 \%)$ & $16(84.21 \%)$ & & $36(16.28 \%)$ & $10(83.33 \%)$ & \\
\hline No & $9(16.08 \%)$ & $60(46,16 \%)$ & & $6(16.67 \%)$ & $3(15.79 \%)$ & & $7(83.72 \%)$ & $2(16.67 \%)$ & n.s \\
\hline
\end{tabular}

a Chi-squared test

${ }^{*} \mathrm{P}<0,05$ : statistically significant.

${ }^{\star *} P<0,001$ : Highly significant.

decay's complications. In addition, the study reported that pregnant women had significantly more gingival recession and periodontitis than non-pregnant women which can be explained by the fact that gingival recession and periodontitis are gingivitis's complications. Indeed, gingivitis is due to the variation in estrogen and progesterone levels in the course of pregnancy that influences subgingival microbiota (the development of Prevotella intermedia) and a range of inflammatory responses in gingival tissues through the changes of chemotaxis, cytokines, enzymes, and antioxidants
$(12,13,24)$. Besides, the studies of Cohen et al, Figuero et al, and Rashidi Maybodi et al, observed an intensification in gingivitis from the first to the third trimester which confirms that gingivitis ameliorates, during pregnancy $(9,25)$. Also, RaberDurlacher et al, and Abraham-Inpijn et al found that changes in clinical parameters during pregnancy are reversible in the postpartum (13). likely, studies who followed 48 pregnant Spanish women with healthy periodontium and examined their periodontium found that their Gingival Index (GI) increased during pregnancy and decreased in postpartum (26). 
Nonetheless, some studies further found that the association between gingivitis and pregnancy is confirmed but combined with poor hygiene (26). Moreover, another study found that pregnant women had significantly higher $\mathrm{Gl}$ and periodontal pocket depth (PPD) with the same plaque index (PI) compared with non-pregnant women (26). In another study with a small sample size of pregnant women, bleeding on probing (BOP) decreased from pregnancy to postpartum without any periodontal therapy (26). Nevertheless, Ait addi et al, Jonsson et al, and Miyazaki et al observed that there was no difference in periodontal status between pregnant and non-pregnant women in a study using clinical parameters (periodontal pocket depth PPD and Gingival index GI), and the community periodontal index of treatment needs (CPITN) to assess the periodontal conditions of pregnant and non-pregnant women $(22,26)$.

In the study findings, pregnant women had more calculus, and brushed their teeth significantly less than non-pregnant women which could be attributed to various reasons: (i) increase in hormones, (ii) leading to more plaque accumulation and gingivitis, (iii) followed by habitual decrease in oral health practices, leading to worsening oral symptoms such as bleeding gums, and surge in dental pain.

Non-pregnant women visited the dentist more than pregnant women. It is explained by the ignorance of dental care utilization during pregnancy and the cultural idea that pregnant women should not visit the dentist.

Lower educational level has been proved as a major risk factor for dental caries (5). Likewise, the study of Wu and al, showed that patients with a lower degree of schooling and lower income had a greater chance of exhibiting periodontitis (26).

Rural living environment is a determinant factor of high frequency of dental decay. Indeed, Karunachandra et al found that rural pregnant women in Sri Lanka have as twice as many untreated dental caries compared with urban women which confirms our results (27).

Numerous population-based surveys of pregnant women report low utilization of dental care and disparities by sociodemographic characteristics. Actually, Care-seeking and utilization are influenced by factors at the personal provider, and environmental levels that include: financial resources and insurance; health literacy regarding knowledge of insurance eligibility; need for care, and perceptions of the importance and value of oral health; the availability of care; access to care; and provider knowledge or comfort in treating pregnant women $(8,15,18,23,28)$.

The results showed that more than $2 / 3$ of the pregnant women consulted a dental quack which may cause major health diseases form of AIDS to hepatitis (29). This can be explained by the poor economic status, the lack of dental insurance, low educational level, and also due to ignorance of the difference between a certified dentist and other (29). Additionally, people use quacks because they guarantee painless and immediate treatment (30). However, it may be due to cultural, sociological and perceptional disparities. Actually, since several decades, Moroccan people used to visit dental quacks before the establishment of dental schools, and thereafter people prefer visit a dental quack than a qualified dentist. Also, because of unconditional traditions people find that these unqualified medical healers are more familiar and competent than qualified dentists.
The limitation of this study is the use of a questionnaire of self-reported dental and periodontal status rather than objective measures of oral diseases and untreated dental needs. However, studies reported that self-reported and clinical surveys had good consistency (31).

\section{CONCLUSION}

Oral health promotion programs must continue to inform pregnant women about proper oral hygiene self-care and utilizing of professional dental care before during and after pregnancy, especially rural and illiterate women. Also, oral health care services should be made more accessible and acceptable to all pregnant women. Finally, programs against illiteracy must continue to reduce illiteracy and also campaigns against illegal practice in dentistry must carry on to secure and improve dental care.

\section{ACKNOWLEDGEMENTS}

We thank coordinators, and all the employees of Zerktouni health center and Attaouia health center. Finally, we are very grateful to all the participants for collecting the data.

\section{REFERENCES}

1. Dye BA, Thornton-Evans G, Li X, Iafolla TJ. Dental caries and tooth loss in adults in the United States, 2011-2012. NCHS data brief, no 197. Hyattsville, MD: National Center for Health Statistics 2015. Available at: https://www.cdc.gov/ nchs/data/databriefs/db197.pdf PMID:25973996

2. Pushpa T, Kumar KA, Suresh M, Abhinav V, Kumar BJ, Meghnath $D$, et al. Oral hygiene practices and their sociodemographic correlates among Nepalese adult: evidence from non communicable diseases risk factors STEPS survey Nepal 2013. BMC Oral Health 2016;16:105. https://doi.org/10.1186/s12903-016-0294-9 PMid:27686858 PMCid:PMC5041565

3. Hybels CF, Wu B, Landerman LR, Liang J, Bennett JM, and Plassman BL. Trends in Decayed Teeth among Middle-Aged and Older Adults in the United States: Socioeconomic Disparities Persist Over Time. J Public Health Dent. 2016 Sep;76(4):287-94. https://doi.org/10.1111/jphd.12153 PMid:27061828 PMCid:PMC5055403

4. Nishi $M$, Harding $M$, Kelleher $V$, Whelton $H$, Allen $F$. Knowledge of caries risk factors/indicators among Japanese and Irish adult patients with different socioeconomic profiles: a cross-sectional study. BMC Oral Health 2017;17:55. https://doi.org/10.1186/s12903-017-0345-x PMid:28209191 PMCid:PMC5314636

5. Vergnes JN, Kaminski M, Lelong N, Musset AM, Sixou M and al. Frequency and Risk Indicators of Tooth Decay among Pregnant Women in France: A Cross-Sectional Analysis. PLoS ONE 2012;7:5. https://doi.org/10.1371/journal.pone. 0033296 PMid:22586442 PMCid:PMC3346733

6. La Marca-Ghaemmaghami P, Ehlert U. Stress during pregnancy. Experienced stress, stress hormones, and protective factors. Eur Psychol 2015;20:102-19. https://doi.org/10.1027/1016-9040/a000195 
7. Xie $Y$, Xiong X, Elkind-Hirsch KE, Pridjian G, Maney $P$, Delarosa RL, et al. Change of periodontal disease status during and after pregnancy 2013. J Periodontol 2013;84(6):725-31. https://doi.org/10.1902/jop.2012.1202 35 PMid:22873653

8. Balan P, He HG, Cao F, Wong ML, Chong YS and al. Oral Health in Pregnant Chinese Women in Singapore: A Call to Go beyond the Traditional Clinical Care. Healthcare 2018;6:77. https://doi.org/10.3390/healthcare6030077 PMid:29987265 PMCid:PMC6163358

9. Chen LW, Low Y L, Fok D, Han WM, Chong YS, Gluckman P and al. Dietary changes during pregnancy and the postpartum period in Singaporean Chinese,Malay and Indian women: The GUSTO birth cohort study. Public Health Nutr 2014;17:1930-8. https://doi.org/10.1017/ S1368980013001730 PMid:23806144

10. Tettamanti L, Lauritano D, Nardone M, Gargari M, Silvestre JR, Gavoglio P, Tagliabue A. Pregnancy and periodontal disease: does exist a two-way relationship? Oral Implantol (Rome) 2017 Apr-Jun;10(2):112-8. https://doi.org/ 10.11138/orl/2017.10.2.112 PMid:29876036 PMCid: PMC5965070

11. Eke PI, Dye BA, Wei L, Thornton-Evans GO, Genco RJ. Prevalence of periodontitis in adults in the United States: 2009 and 2010. J Dent Res 2012;91(10):914-20. https://doi.org/10.1177/0022034512457373 PMid:22935673

12. Figuero E, Carrillo-de-Albornoz A, Martın C, Tobıas A, Herrera D. Effect of pregnancy on gingival inflammation in systemically healthy women: a systematic review. J Clin Periodontol 2013;40:457-73. https://doi.org/10.1111/ jcpe.12053 PMID: 23557432

13. González-Jaranay, Téllez L, Roa-López A, Gómez-Moreno G, Moreu G. Periodontal status during pregnancy and postpartum. PLoS One 2017 May 19;12(5):e0178234. https://doi.org/10.1371/journal.pone.0178234 PMid:28538740 PMCid:PMC5438174

14. Wu Y.M, Ren F, Chen LL, Sun WL, Liu J, et al. Possible socioeconomic and oral hygiene behavioural risk factors for self-reported periodontal diseases in women of childbearing age in a Chinese population. Oral Health Prev. Dent 2014;12:171-81. https://doi.org/10.3290/j.ohpd.a3 1671

15. Hartnett E, Haber J, Krainovich-Miller B, Bella A, Vasilyeva A, Lange Kessler J. Oral Health in Pregnancy. J Obstet Gynecol Neonatal Nurs 2016 Jul-Aug;45(4):565-73. https://doi.org/10.1016/j.jogn.2016.04.005 PMid:27281467

16. Capasso F, Vozza I, Capuccio V, Vestri AR, Polimeni A, Ottolenghi L. Correlation among periodontal health status, maternal age and pre-term low birth weight. Am. J. Dent 2016;29:197-200. Available at: https://europepmc.org/ article/med/29178747

17. Daalderop LA, Wieland BV, Tomsin K, Reyes L, Kramer BW, et al. Periodontal Disease and Pregnancy Outcomes: Overview of Systematic Reviews. JDR Clin Trans Res 2018 Jan;3(1):10-27. https://doi.org/10.1177/2380084417731097 PMid:30370334 PMCid:PMC6191679

18. Wallace B, Browne AJ, Varcoe C, et al. Self-reported oral health among a community sample of people experiencing social and health inequities: crosssectional findings from a study to enhance equity in primary healthcare settings. BMJ Open 2015;5:e009519. https://doi.org/10.1136/ bmjopen-2015-009519 PMid:26700285 PMCid:PMC4691735
19. Boggess KA, Edelstein BL. Oral Health in Women During Preconception and Pregnancy: Implications for Birth Outcomes and Infant Oral Health. Matern Child Health J. 2006 Sep;10(Suppl 1):169-74. https://doi.org/10.1007/ s10995-006-0095-x PMid:16816998 PMCid:PMC1592159

20. High Commission for the Plan, Note on the first results of the General Census of Population and Housing 2014. Available at: https://www.hcp.ma/Repartitiongeographique-de-la-population-d-apres-les-donnees-duRecensement-General-de-la-Population-et-de-l-Habitatde_a1796.html

21. Silk H, Douglass AB, Douglass JM, Silk L. Oral health during pregnancy. Am. Family Phys., 2008;77:1139-44. Available at: https://www.aafp.org/afp/2008/0415/p1139.html

22. Addi RA, Benksim A, Zouini M, Cherkaoui M. A Crosssectional Study of Socio-demographic Characteristics of Pregnant Women on the Dental and Periodontal Health. Asian Journal of Epidemiology 2018;11:14-9. https://doi.org/10.3923/aje.2018.14.19

23. Chung LH, Gregorich SE, Armitage GC, Vargas JG, and. Adams SH. Sociodemographic disparities and behavioral factors in clinical oral health status during pregnancy. Community Dent Oral Epidemiol. 2014 April;42(2):151-9. https://doi.org/10.1111/cdoe.12075 PMid:24117710 PMCid: PMC3960354

24. Wu M, Chen, SW, Jiang SY. Relationship between Gingival Inflammation and Pregnancy. Hindawi Publishing Corporation Mediators of Inflammation 2015;11:Article ID 623427. https://doi.org/10.1155/2015/623427 PMid:25873767 PMCid:PMC4385665

25. Rashidi Maybodi F, Haerian-Ardakani A, Vaziri F, Khabbazian A, Mohammadi-Asl S. CPITN changes during pregnancy and maternal demographic factors 'impact on periodontal health. Iran J Reprod Med 2015;13:107-12. PMID:26000000

26. Piscoya MD, Ximenes RA, Silva GM, Jamelli SR, Coutinho SB. Periodontitis-associated risk factors in pregnant Women. CLINICS 2012;67(1):27-33. https://doi.org/10.6061/clinics/ 2012(01)05 PMID:22249477

27. Karunachandra NN, Perera I, Fernando G. Oral health status during pregnancy: rural-urban comparisons of oral disease burden among antenatal women in Sri Lanka. Rural and Remote Health 2012;12:1902. Available at: www.rrh.org.au/journal/article/1902

28. Mashoto KO, Astrom AN, Skeie MS, Masalu JR. Sociodemographic disparity in oral health among the poor: a cross sectional study of early adolescents in Kilwa district, Tanzania. BMC Oral Health 2010;10:7. https://doi.org/10.1186/1472-6831-10-7 PMid:20406452 PMCid:PMC2868779

29. Kumari S, Mishra SK, Mishra P. An evidence-based review on quackery in dentistry. BLDE University Journal of Health Sciences 2018;3:75-8. Available at: http://www.bldeu journalhs.in/article.asp?issn=2468-838X; year=2018; volume $=3$; issue $=2$; spage $=75$; epage $=78$; aulast=Kumari

30. Reddy KV, Bansal V, Singh PK, Bhambal A, Gupta M and al. Perceptions Regarding Treatment by Dental Quacks and Self-Rated Oral Health Among the Residents of Bhopal City, Central India. J Indian Assoc Public Health Dent 2017; 15:84-8. Available at: http://www.jiaphd.org/article.asp? issn=2319-5932; year=2017; volume=15; issue=1; spage=84; epage $=88$; aulast $=$ Reddy 
31. Thomas J III, Paulet M, Rajpura JR. Consistency between Self-Reported and Recorded Values for Clinical Measures. Cardiology Research and Practice 2016;6:Article ID 4364761. https://doi.org/10.1155/2016/4364761 PMid:26942034 PMCid:PMC4752969 